\title{
Increased of Brazilian productivity in the slaughterhouse sector: a review
}

\author{
Márcia Rosângela Buzanello ${ }^{\mathrm{a}, \mathrm{b}^{*}}$ and Antônio Renato Pereira Moro ${ }^{\mathrm{c}, \mathrm{d}}$ \\ ${ }^{a}$ Post-graduation Program in Production Engineering, Laboratory of Biomechanics, Federal \\ University of Santa Catarina, SC, Brazil; \\ ${ }^{b}$ Department of Physical Therapy, State University of West of Paraná, Cascavel, PR; \\ ${ }^{\mathrm{c}}$ Post-graduation Program in Production Engineering, Laboratory of Biomechanics, Federal \\ University of Santa Catarina, SC, Brazil; \\ ${ }^{d}$ Department of Physical Education, Laboratory of Biomechanics, Federal University of Santa Catarina, SC, \\ Brazil.
}

\begin{abstract}
Due to Brazil is a tropical country has activities in occupational exposure to cold restricted to few sectors especially the meatpacking industry. Taking into account that the country in 2010, was again the largest exporter of poultry meat in the world and consequently employing a large number of workers for their slaughter and processing. The search for greater productivity can result in an increase in work rate, as indicated in this sector as monotonous, repetitive and uncomfortable. According the Programa de Frigorifico it was found that within six years, about $20 \%$ of the six thousand workers in a slaughterhouse in southern Brazil, received welfare benefits due to musculoskeletal diseases. Adding to this, the lack of parameters for the Brazilian standardization concerning occupational activities carried out in cold. Although several epidemiological studies point to the cold as a risk factor for occurrence or aggravation of musculoskeletal disorders, research in this field is still limited and often contradictory conclusions. This article aims to review developments concerning the poultry industry and the fridge in Brazil, as well as raising the question about the increased productivity of the slaughterhouse, since it has already shown a high prevalence of musculoskeletal disorders related to work.
\end{abstract}

Keywords: Poultry, Cold, Musculoskeletal disorders

* Correponding author. Email: mrbuzanello@yahoo.com.brBrazil, General Rondon, 1559, Zip code 85901-160, Toledo, PR, Brazil 


\section{Introduction}

The Brazilian poultry industry is a sector of the contemporaneous economy has undergone profound changes over the past 40 years, presenting a set of changes related to the organizational structure encompassing much of the production processes, administrative and work organization. Leaving the familiar and traditional production for the poultry industry. The industrialization of the sector at the beginning of the 60 's, but the movement of expansion and intensification began in the year 1970. Becoming one of the leading sectors in technology and production, both in supplying the domestic market and in exports, Dalla Costa [1]. Dalla Costa [2] comments on the consequences of deploying a modern industrial park from the 70's. Making industrialization responsible for changing the geographical center of the national poultry production. Before 60 years, the South dominated the Brazilian production and distribution. With the start of the activities of companies in the South, the main focus of the industry moved to Paraná, Santa Catarina and Rio Grande do Sul, while Sao Paulo remains the only state with significant production in the Southeast. The population growth and urbanization were significant factors which, together with technological and organizational changes, drove the increases in output.

The current segment of the poultry industry organization, dedicated to meet the growing demand and new markets, resulted in changes in production patterns.

However in the study by Barth and Guimarães [7] despite advances in the technological level, represented by the rigid control of cooling and the mechanization of norea carrier, among others, none breakthrough occurred in the project work in various positions in the poultry sector, with workers required increasing levels of productivity and quality of cut, at the expense of labor-intensive and exhausting in terms of a rigid system of production Taylorist/Fordist. The Brazilian poultry industry represented $55 \%$ of production in Latin America in 2008, but with the economic scenario of the poultry sector is showing increasing in elevation and a presence in the export of meat. In the same year the activity generated over 4 million direct and indirect jobs in Brazil and in 2010 began to employ over 4.5 million workers, UBABEF [15].

\section{Evolution of poultry in Brazil and internacional market}

The international market is increasingly open to Brazilian poultry. Between January-February 2010, Brazil exported $517,341,715$ pounds of poultry. In 2010 , consolidated the position one more time, won in 2004 for world's largest exporter of poultry meat UBABEF [15].

According to the Agro Link [3] only in February 2011 , the country exported $283,220,421$ pounds of broiler poultry, performance, $6.95 \%$ over the same period in 2009. Paraná is national prominence in foreign sales of the product, accounting for one fourth of the total volume sold by Brazil in the international market. In the first two months of 2010, according to the numbers from Syndicate of Poultry Products Industries of the State of Paraná, SINDIAVIPAR [14] the state exported $131,246,238$ pounds of poultry. In the positive scenario and on the rise, domestic producers, focusing on the growth of international sales, are using to open new doors for business in the external sector. A deeper knowledge of the consumption characteristics of each country has proved an effective alternative in the conquest of new markets for Brazilian poultry meat in the Middle East and Asia, the main destinations for Brazilian poultry.

\section{Increased of productivity: musculoskeletal consequences}

Conform Belusso and Hespanhol [6] it is known that the greatest interest in poultry specialist is guided in a significant evolution in poultry production in Brazil due to improvements in handling and equipment used in seeking an international quality standard, in addition to increased consumption of poultry meat in the domestic market driven by more affordable and to attract foreign share of the market, which is also expanding.

The slaughterhouse cutting room has the main task characterized as essentially manual, where the skiver is the tool used, driven exclusively by muscular contraction of the worker Buzanello, Merino and Moro [13]. Based on results obtained in the study of Chiang et al [10] Griefahn et al [5] and Oksa et al [11] both, exposure to unpleasant working environment and high repeatability assume the risk of increasing health problems, including musculoskeletal disorders. According to statistics Brandão[13] we can say that $20 \%$ of those who work in slaughter and meat processing 
musculoskeletal disorders will face throughout their working life.

According to Rizzi [4] the technological level of the production process on this date was already approaching the international level, but there was a delay due mainly to the existence of abundant natural resources and a poorly paid labor force, which tended to compensate for cost reduction associated with incorporating new technologies. 'That is still a reality nowadays and why the need for manual cutting process.

The sectors of bleeding, scalding and plucking are the least employed workers, that because machines are used, but from the moment when the bird is clean on the outside, the incorporation of workers is higher. Fact explained by the need for much of the work by hand, making minimal use of machines. Even because of requirements in export contracts, the socalled special courts, where the products have higher added value and to ensure a proper fit must be prepared manually, since the machine can not adapt to the different sizes of birds. And therefore, the main feature of workmanship incorporated into the production process of slaughterhouse should be agility, speed and manual dexterity. Work tasks in the food processing industry are often repetitive and monotonous and the workers perform their tasks in a high rate of speed, while the ergonomic factors are not always the most favorable, Campbell [8], Buzanello, Moro and Martins [12].

And in the other hand, according to Belusso and Hespanhol [6] it is precisely in making cuts that require the use of manual labor, that the Brazilian industry is in greatest advantage compared to international companies. Manual labor is still ensuring the quality of the cuts, due to the lack of appropriate technology for this purpose. One feature, the expansion in the international market is the service the requirements of foreign markets, in accordance with the precepts of the Koran to the Muslim and manuals cuts for the Japanese marke for example.

\section{Conclusion}

In Brazil, there are high rates of occupational diseases among workers in a slaughterhouse, repetitive strain injuries and the psychological disorders. With the increased of poultry production and processing the search for greater productivity can result in longer working hours and overtime hour. So, there is a concern regarding the musculoskeletal injury score.

\section{Acknowledgements}

Thanks to UNIOESTE and UFSC for financial help.

\section{References}

[1]A. Dalla Costa (2008). Contratos, novas tecnologias e produtividade do trabalho entre os avicultores do Sul do Brasil. Revista Brasileira de inovação. 7 (2), p.313-340, jul/dez.

[2] A. Dalla Costa (2010, dec 01). Avicultura brasileira. Retrieved from: http://www.agronet.com.br/avicultura1.htm.

[3] Agro Link (2010, april 10). Frango brasileiro abre espaço no mercado oriental. Retrieved from: http://www.agrolink.com.br

[4] A. T. Rizzi (1993). Mudanças Tecnológicas e Reestruturação da Indústria Agroalimentar: o caso da indústria de frangos no Brasil. 1993. 194f. Tese (Doutorado em Economia), Instituto de Economia da Universidade Estadual de Campinas UNICAMP, Campinas.

[5] B. Griefahn, P. Mehnert, P.Bröde and A. Forsthoff. Working in moderate cold: a possible risk to health. J Occup Health , 39: 36-44 (1997)

[6] D. Belusso and A.N. Hespanhol. Cooperativismo agroindustrial e expansão da avicultura de corte no oeste do Paraná. Gestão econômica e social de cooperativas. In: Proocedings of the V Encontro de pesquisadores Latino-americanos de Cooperativismo. Ribeirão Preto - São Paulo - Brasil. 06-8 de agosto, 2008.

[7] D.C. Barth and L. B. de M. Guimarães. Análise do impacto do rodízio no grau de risco postural e de desconforto/dor de trabalhadores na desossa de frango. In: Proocedings of ABERGO 2008. Porto Seguro-Bahia-Brazil. 23-25-jule, 2008.

[8] D. T. Campbell. Health hazards in the meatpacking industry. Occup Med, 14(2), 351-372 (1999).

[9] G. Brandão. Agência Senado (2010, sep 12) . Retrieved from: http://www.senado.gov.br

[10] H.C. Chiang, S.S. Chen, H.S. Yu and Y.C. Ko. The occurrence of carpal tunnel syndrome in frozen food factory employees. Kaohsiung. J Med Sci, 6: 73-80 (1990).

[11] J. Oksa. Neuromuscular performance limitations in cold. Int $\mathbf{J}$ Circumpolar Health, 61(2), 154-162 (2002).

[12] M. R. Buzanello, A. R. P. Moro and Martins, C. V. B. Impact of musculoskeletal diseases in slaughterhouse's workers exposed to cold in southern Brazil. In: Proocedings of the $9^{\text {th }}$ Pan- Pacific of Conference on Ergonomics. Kaochung Taiwan, 07- 10-nov, 2010.

[13] M.R. Buzanello, E. A. Merino and A. R. P. Moro. Attributes of comfort, productivity, quality and usability of boning in a bird's slaughterhouse in Brazil. In: Proocedings of the $9^{\text {th }}$ PanPacific of Conference on Ergonomics. Kaochung-Taiwan, 07- 10-nov, 2010.

[14]Sindicato das indústrias de produtos agrícolas do Paraná SINDIAVIPAR. (2010, apr Frango brasileiro abre espaço no mercado oriental. Retrieved from: http://www.sindiavipar.com.br/

[15] União Brasileira de Avicultura - UBABEF (2010, dec 10) Exportações brasileiras de carne de frango. Retrieved from: http://www.abef.com.br. 